\title{
Unusual organ involvment in Henoch-Schönlein purpura patients; a roprt from Iran
}

\author{
Vahid Ziaee ${ }^{1,2^{*}}$, Mohamad-Hassan Moradinejad ${ }^{1}$ \\ From 18th Pediatric Rheumatology European Society (PReS) Congress \\ Bruges, Belgium. 14-18 September 2011
}

\section{Background}

Henoch-Schönlein purpura (HSP) is the most common vasculitis in children. The common presentation in this disease is coetaneous, gastrointestinal (GI), joint and renal involvement, but sometimes unusual organ can be involvement in this disease.

\section{Aim}

To evaluate unusual organ involvement in HSP.

\section{Methods}

In a prospective study (2009 and 2010), all patients who had HSP diagnosis enrolled in this study. The diagnosis was established based on the ACR criteria. All organ involvement was evaluated and skin biopsy was done for all patients. In addition usual laboratory evaluation, other necessary investigation such as testicular Doppler ultrasound, brain CT scan was performed in selected cases.

\section{Findings}

Out of 85 patients $34.2 \%$ was female and $65.8 \%$ were male (mean age $6.5 \pm 3.9$ years). Clinical symptoms were skin involvement in all patients (100\%), GI involvement in $70.6 \%$, joint and renal involvement (in acute phase) in $57.6 \%$ and $21.2 \%$, respectively. Out of 56 male patients, $35.7 \%$ had genitalia involvement $(75 \%$ scrotal swelling, $45 \%$ epididimo-orchitis like symptoms, $5 \%$ penis inflammation, and 5\% meatus inflammation ).

Central nervous system (CNS) involvement was found in $8.2 \%$ (71.4\% headache, seizures and sleep disorders each one $28.5 \%$, and confusion in one patient). Pinna perichondritis (PP) was detected in 3 patients (3.5\%)

\footnotetext{
* Correspondence: ziaee@tums.ac.ir

'Department of Pediatrics, Tehran University of Medical Sciences, Tehran, IR Iran

Full list of author information is available at the end of the article
}

which all of them were male and they had genitalia involvement. There is a significant relation between age and PP and all patients had age less than 5 years. There is no significant relation between age or sex and genitalia or CNS involvement.

\section{Conclusion}

Genitalia involvement is a common in HSP. PP is a benign and uncommon involvement in HSP especially in male patients. Also, CNS involvement is uncommon but serious involvement is rare.

\section{Author details}

${ }^{1}$ Department of Pediatrics, Tehran University of Medical Sciences, Tehran, IR Iran. ${ }^{2}$ Growth and Development Research Center, Tehran University of Medical Sciences, Tehran, IR Iran.

Published: 14 September 2011

doi:10.1186/1546-0096-9-S1-P99

Cite this article as: Ziaee and Moradinejad: Unusual organ involvment in Henoch-Schönlein purpura patients; a roprt from Iran. Pediatric Rheumatology 2011 9(Suppl 1):P99.

Submit your next manuscript to BioMed Central and take full advantage of:

- Convenient online submission

- Thorough peer review

- No space constraints or color figure charges

- Immediate publication on acceptance

- Inclusion in PubMed, CAS, Scopus and Google Scholar

- Research which is freely available for redistribution

\section{() Biomed Central}

